\title{
KAJIAN APLIKASI TEKNOLOGI INSEMINASI BUATAN \\ DALAM UPAYA PENINGKATAN PRODUKTIVITAS DAN PENDAPATAN USAHA TERNAK SAPI POTONG DI KABUPATEN TASIKMALAYA
}

\author{
Oleh : \\ SUPRIANTO \\ DOSEN PRODI AGRIBISNIS FAKULTAS PERTANIAN \\ UNIVERSITAS SILIWANGI \\ e-mail : supriantoprie56@gmail.com \\ DEDI DJULIANSAH \\ DOSEN PRODI AGRIBISNIS FAKULTAS PERTANIAN \\ UNIVERSITAS SILIWANGI \\ e-mail :dedidjuliansah@ rocketmail.com
}

\begin{abstract}
The Increasing of Productivity and Cow Farmers Income By Artificial Insemination. Case Study at Distict of Tasikmalaya.
\end{abstract}

The aims of this research are to know: level of productivity and income of cow farmers by artificial insemination, and natural farmer; in Tasikmalaya. Survey was the method used. There were 15 farmer as sampling unit of The Insemination Farmer and 17 the natural farmer.

The result of the research can be concluded that: The produkductivity of artificial insemination farmer more than the productivity of natural farmer; both of the farmers were on equal fragnant productivity. It were one baby cow for one time of the fragnan. But the artificial insemination farmer have short interval. On 23 Th months the artificial insemination farmers have two times fragnant; the growth rate of the artificial insemination cow was faster then the growth rate of the natural cow. The baby cow by artificial insemination reach $105-110 \mathrm{~kg}$ on 4 Th months, but the natural were only 65-75 $\mathrm{kg}$ on 6-8 Th months. Net income of artificial insemination farmers were 5,65 percents on the total investments, while the natural farmer were 3,44 percent per month.

Kata kunci : Inseminasi, Produktivitas, cow farmers

\section{PENDAHULUAN}

Kelangkaan daging sapi di pasaran akhir-akhir ini cukup menyita perhatian masyarakat. Harga daging sapi melambung tinggi mencapai angka $\mathrm{Rp} 130$ ribu rupiah perkilogramnya. Laju permintaan daging sapi jauh lebih besar dari laju pertambahan produksi.Maka usaha ternak yang bertujuan memproduksi daging memiliki prospek yang cukup baik. Sebagai gambaran, rata-rata konsumsi daging penduduk Indonesia saat ini hanya sekitar $2 \mathrm{~kg} / \mathrm{kapita} / \mathrm{tahun}$, masih sangat rendah apabila dibandingkan dengan rata-rata konsumsi daging penduduk negara tetangga Australia yang telah mencapai sekitar 40 $\mathrm{kg} / \mathrm{kapita} /$ tahun (Rasyaf M, 2006). Artinya, kalau menggunakan standar konsumsi daging penduduk Australia, potensi permintaan daging nasional masih dapat ditingkatkan duapuluh kali lipat.

Ironisnya untuk mencukupi kebutuhan daging nasional saat ini saja, Indonesia masih harus impor daging, bahkan mengimpor sapi dalam jumlah cukup besar.Impor sapi mencapai 500.000 ekor per tahun dengan nilai mendekati 2 trilyun rupiah. Kondisi seperti ini semakin meyakinkan bahwa peluang pengembangan usaha ternak sapi di Indonesia, khususnya di Kabupaten Tasikmalaya saat ini masih cukup prospektif.

Mengantisipasi kebutuhan daging nasional yang cenderung semakin meningkat, Pemerintah melalui Direktorat Jenderal Produksi Peternakan telah mencanangkan 


\section{A MIMBAR \\ AGRIBISNIS}

ISSN 2460-4321

Volume 1 • Nomor 3 • Juli 2016

program swasembada daging sapi.Swasembada daging diartikan sebagai tersedianya secara cukup pangan asal hewan sampai tingkat rumah tangga dengan harga terjangkau. Konsep swasembada daging dapat bersifat ontrend, artinya suatu saat dapat melakukan ekspor, namun tidak tertutup kemungkinan impor dalam jumlah terbatas (Sudrajat, 2000). Dalam keadaan cadangan devisa negara yang terbatas, pemenuhan kebutuhan daging secara mandiri lebih baik daripada pemenuhan kebutuhan dengan cara impor.

Kabupaten Tasikmalaya merupakan salah satu kawasan potensial sebagai sentra produksi dan termasuk kawasan andalan pengembangan sapi potong di Jawa Barat.Kabupaten Tasikmalaya termasuk kawasan pengembangan sapi potong "Cipamatuh", yang pernah dicanangkan pemerintah Propinsi Jawa Barat.Namun demikian peternak-peternak yang ada di wilayah Kabupaten Tasikmalaya sendiri, sampai saat ini belum mampu untuk memenuhi permintaan daerahnya sendiri.

Permintaan sapi potong untuk wilayah Kabupaten Tasikmalaya dan Priangan Timur merupakan pasar efektif yang dapat dijadikan prioritas sasaran pemasaran. Sebagai ilustrasi, kebutuhan sapi potong khusus wilayah Kota Tasikmalaya setiap tahunnya mencapai 12.000 ekor atau setara dengan 33 ekor sapi per hari. Menurut Sub Dinas Peternakan Kabupaten Tasikmalaya, untuk memenuhi kebutuhan daging sapi wilayah Kota Tasikmalaya, 85 persen masih didatangkan dari luar daerah, artinya peternak sapi lokal hanya mampu mengisi pangsa pasar sebesar 15 persen. Selebihnya, untuk memenuhi permintaan daging sapi di Tasikmalaya mendatangkan sapi dari Propinsi Jawa Tengah, Jawa Timur dan Lampung. Kebutuhan daging sapi tersebut kadang-kadang dipenuhi dengan sapi impor asal Australia.

Persoalannya, untuk memenuhi permintaan pasar lokal tersebut, dalam kalkulasi matematis setidaknya diperlukan populasi induk sebanyak 1,5 kali angka pemotongan di tambah final stock (ternak yang dibesarkan dan digemukkan) 3 kali dari angka pemotongan dan ternak pengganti sapi induk sebesar $20 \%$ dari populasi induk. Alternatif lain untuk memenuhi kebutuhan daging sapi secara mandiri di Tasikmalaya, harus di back up dengan populasi sapi minimal 67 ribu ekor. Sedangkan populasi hanya mencapai sepertiganya (Dinas Peternakan, Perikanan dan Kelautan Kab. Tasikmalaya 2011).

Faktor yang diduga sebagai penyebab rendahnya populasi ternak sapi di Indonesia, khususnya di Kabupaten Tasikmalaya adalah produktivitasnya yang rendah.Sedangkan rendahnya produkstivitas terkait dengan tatalaksana usaha ternak yang masih dibawah standar minimal. Hal ini dicirikan dengan cara pemeliharaan yang masih tradisional. Kesungguhan peternak juga belum teruji dengan menempatkan usaha ternaknya sebagai usaha sampingan.Masih banyak hal yang semestinya dilakukan oleh peternak dalam pelaksanaan pemeliharaan ternaknya.Inputinput produksi masih dalam dosis yang rendah, juga mutu yang belum memadai, maka sangat logis apabila hasil usaha belum maksimal (Subdin Peternakan 2001).

Salah satu upaya untuk meningkatkan produktivitas usaha ternak adalah melalui penerapan teknologi Inseminasi Buatan (IB).Inseminasi buatan merupakan terjemahan dari artificial insemination.In berarti pemasukan, dan semen berarti cairan (plasma semen) yang mengandung sel-sel kelamin jantan atau spermatozoa (Toelihere,1985). Perlu dijelaskan bahwa spermatozoa diperoleh melalui proses ejakulasi pada waktu terjadi kopulasi. Penampungan semen pada waktu terjadi kopulasi menggunakan vagina buatan (artificial vagina).

Tujuan dilaksanakannya aplikasi teknologi IB dapat dilihat dari sisi mikro dan makro yang selaras.Tujuan dari sisi mikro introduksi IB dimaksudkan untuk meningkatkan produkstivitas dan kualitas usaha ternak.Semen yang diintroduksikan tentunya diperoleh dari sapi jantan unggul, harapannya keturunan yang diperoleh juga mendekati kualitas sumber semen tersebut.Pada gilirannya, peningkatan produktivitas dan kualitas usaha ternak dapat meningkatkan pendapatan peternak.Sedangkan tujuan dari sisi makro, introduksi IB untuk meningkatkan populasi dan 


\section{Kajian Aplikasi Teknologi Inseminasi Buatan Dalam Upaya Peningkatan Produktivitas Dan \\ Pendapatan Usaha Ternak Sapi Potong \\ Di Kabupaten Tasikmalaya \\ SUPRIANTO DAN DEDI DJULIANSAH}

produksi, agar dapat memenuhi permintaan yang selama ini masih harus dipenuhi melalui impor.

Dalam upaya untuk mewujudkan swasembada daging sapi dilakukan dengan beberapa strategi kebikakan pemerintah yaitu (1) Peningkatan produktivitas; dengan cara meningkatkan kegiatan transfer embrio dan inseminasi buatan (IB) secara terpadu, terkonsentrasi dan diikuti dengan program penggemukan; (2) Meningkatkan populasi ternak antara lain dengan pengendalian pemotongan betina produktif; (3) Substitusi dan diversifikasi serta (4) Pengembangan kelembagaan.

Teknik inseminasi buatan sebetulnya telah diperkenalkan di Indonesia sejak tahun 1950-an. Penerapan secara meluas tanpa perencanaan yang matang selama kurang lebih 20 tahun telah menyebabkan lebih banyak kegagalan daripada keberhasilan (Toilehere, 1985). Upaya penerapan teknologi inseminasi buatan di Kabupaten Tasikmalaya dimulai sejak tahun 1999 dengan bantuan anggaran biaya proyek yang bersumber dari APBN dan APBD Tingkat I. Namun demikian perkembangannya program inseminasi buatan mengalami stagnasi, sehingga hasilnya belum memuaskan.

Beranjak dari kondisi inilah penelitian ini mencoba mambuat fokus analisis yang tujuannya untuk memberikan gambaran kepada pihak-pihak yang berkepentingan, bahwa aplikasi teknologi IB memang memerlukan biaya. Namun demikian melalui aplikasi teknologi IB ini diharapkan akan meningkatkan produktivitas dan produksi. Pada gilirannya akan meningkatkan tambahan penerimaan yang jauh lebih besar dari besarnya tambahan biaya yang dikeluarkan.

Berdasarkan latar belakang masalah yang telah diuraikan tersebut di atas, penelitian ini bertujuan untuk mengetahui :

1. Karakteristik peternak sapi potong, baik yang mengaplikasikan teknologi inseminasi buatan IB, maupun peternak sapi potong yang tidak mengaplikasikan teknologi IB.

2. Produktivitas usaha ternak sapi potong rakyat dengan teknologi inseminasi buatan dan produktivitas usaha ternak sapi potong tanpa IB.

3. Pendapatan peternak sapi potong rakyat yang melaksanakan IB dan yang tidak melaksanakan IB.

4. Risiko dan Manfaat dari aplikasi teknologi inseminasi buatan terhadap usaha ternak sapi potong pada umumnya.

\section{Urgensi Kajian}

Kelangkaan daging sapi memberi dampak yang signifikan terhadap perekonomian nasional, dan ditanggapi serius oleh para pedagang daging di Jakarta dan kota-kota besar lainnya dengan melakukan mogok berdagang.Respon masyarakat juga cukup kuat terhadap kelangkaan daging sapi ini, sehingga berdampak sosial yang cukup luas. Berkaitan dengan hal tersebut, penelitian ini merespon fenomena yang terjadi pada komoditas daging sapi melalui identifikasi permasalahan pada tingkat on farm, khususnya di beberapa wilayah kecamatan di bagian Selatan Kabupaten Tasikmalaya.

\section{Hasil Yang Ditargetkan}

Paling tidak terdapat point hasil yang diharapkan dari pelaksanaan penelitian ini diantaranya adalah :

1. Teridentifikasinya karakteristik peternak sapi potong di Kabupaten Tasikmalaya, baik yang mengaplikasikan teknologi IB maupun peternak yang tidak mengaplikasikan teknologi IB.

2. Teridentifikasinya perbandingan produktivitas usaha ternak sapi potong rakyat dengan teknologi IB dan bukan IB di Kabupaten Tasikmalaya

3. Teridentifikasinya perbandingan pendapatan peternak sapi potong rakyat yang melaksanakan IB dan yang tidak melaksanakan IB di Kecamatan Kabupaten Tasikmalaya

4. Teridentifikasinya risiko usaha ternak sapi potong rakyat dengan aplikasi teknologi IB. 


\section{A MIMBAR \\ AGRIBISNIS}

ISSN 2460-4321

Volume 1 • Nomor 3 • Juli 2016

\section{METODE PENELITIAN}

Penelitian yang dilaksanakan ini termasuk kategori deskriptif-eksplanatori, yang berupaya diarahkan untuk menjelaskan dampak introduksi teknologi inseminasi terhadap produktivitas dan pendapatan usaha ternak sapi.

\section{Sumber dan Teknik Pengumpulan Data}

Berdasarkan langsung tidaknya data diperoleh dari sumbernya, jenis data dapat diklasfikasikan menjadi dua kategori, yaitu data primer dan data sekunder.

Data primer adalah data yang diperoleh dari responden secara langsung, pengumpulannya melaui survey dan wawancara.

Data sekunder adalah data yang diperoleh tidak langsung dari responden, namun didapat dari institusi pemerintah maupun swasta diperoleh melalui studi literatur yang ada kaitannya dengan masalah penelitan.

\section{Teknik Penarikan Sampel}

Studi ini merupakan kajian yang bersifat komparatif, membandingkan keadaan usaha peternak sapi yang melakukan aplikasi teknologi IB, dengan usaha peternak sapi potong yang tidak melakukan aplikasi teknologi IB. Dengan demikian untuk penetapan sampel dilakukan klaster (cluster random sampling).

Berdasarkan hasil observasi awal, diketahui jumlah populasi peternak di lokasi kajian 156 orang. Dari jumlah tersebut 70 diantaranya telah melakukan introduksi teknologi IB, dan sisanya sebanyak 86 peternak merupakan peternak yang belum atau tidak melaksanakan IB. Diantara populasi peternak tersebut, sebanyak 15 peternak dijadikan responden untuk peternak yang melaksanakan teknologi IB dan 17 peternak dijadikan responden untuk peternak yang tidak melakukan aplikasi teknologi IB. Penetapan responden dilakuan secara purposif.

Hubungan antara aplikasi teknologi IB dengan pendapatan peternak adalah hubungan yang tidak langsung. Tenologi IB secara teoritis meningkatkan produktivitas, yang pada gilirannya akan mempengaruhi pendapatan. Maka yang dimansud variabel interfining dalam penelitian ini adalah produktivitas.

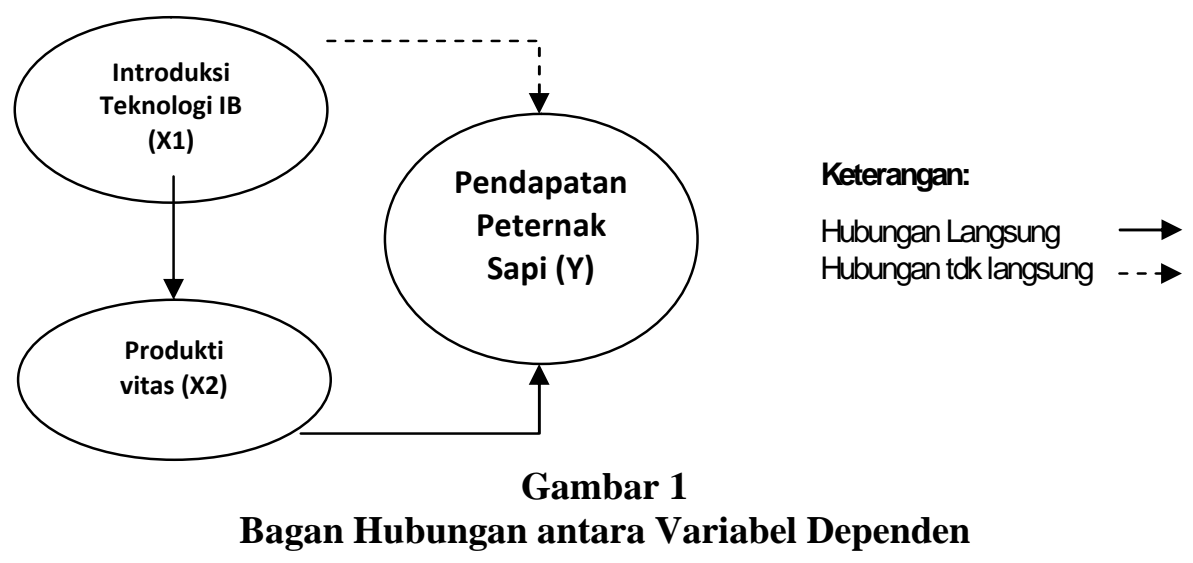

\section{Independen dan Interfining Dalam Kajian}

Variabel-variabel yang diamati dalam penelitian diberi batasan terlebih dahulu agar menjadi jelas difinisi operasionalnya, sehingga dapat diukur indikator dan cara pengukurannya:

- Inseminasi buatan IB adalah perlakuan pemasukan atau penyampaian semen ke dalam saluran kelamin sapi betina dengan alat-alat buatan manusia. Perlakuan IB dihitung dalam satuan frekuensi untuk satu induk satu kehamilan.

$\bullet$ Produktivitas

berarti jumlah produksi per satuan faktor produksi. Berdasarkan pengertian tersebut, pengertian produktivitas dalam penelitian ini berarti : 


\section{Kajian Aplikasi Teknologi Inseminasi Buatan Dalam Upaya Peningkatan Produktivitas Dan Pendapatan Usaha Ternak Sapi Potong Di Kabupaten Tasikmalaya \\ SUPRIANTO DAN DEDI DJULIANSAH} induk dalam kurun waktu tertentu dinyatakan dalam satuan ekor per periode waktu tertentu.

$\bullet$ adalah jumlah uang hasil penjualan produk fisik dikalikan harga per satuan produk. Untuk mengukur penerimaan dalam penelitian ini dilakukan dengan cara mengkalikan jumlah anakan yang dihasilkan oleh induk dalam periodisasi tertentu untuk penjualan anak dan jumlah bobot sapi dikalikan dengan harga per kilogram sapi. Penerimaan dinyatakan dalan satuan rupiah.

Biaya Produksi adalah seluruh keluaran yang terjadi untuk mendukung proses produksi, baik secara langsung maupun tidak langsung.

\section{Kerangka Analisis dan Uji Hipotesis}

Pendapatan usahatani digambarkan sebagai sisa pengurangan nilai-nilai penerimaan usahatani dengan biaya yang dikeluarkan sedangkan penerimaan adalah hasil perkalian dari jumlah produksi total dengan harga jual, sedangkan pengeluaran atau biaya usahatani adalah nilai penggunaan sarana produksi dan lain-lain yang diperlukan atau dibebankan pada proses produksi yang bersangkutan (Abas Tjakrawiralaksana, 1983).

Penerimaan $=$ total produksi $\mathrm{x}$ harga jual

Pendapatan $=$ penerimaan - biaya produksi total Analisis yang digunakan dalam penelitian ini yaitu dengan melihat perbandingan antara penerimaan dengan biaya total atau $\mathrm{R} / \mathrm{C}$ ratio, sehingga dari hasil perbandingan dapat dilihat tingkat keberhasilan dan efisiensi usahatani (Abas Tjakrawiralaksana, 1983) dengan rumus :

$$
\mathrm{R} / \mathrm{C} \text { ratio }=\frac{\text { Penerimaan }}{\text { biaya total }}
$$

Terdapat tiga kemungkinan kesimpulan hasil analisis dari rumusan tersebut diatas yaitu sebagai berikut:

- Revenu costs ratio (R/C) > 1 usahaternak sapi layak dijalankan.
Revenu costs ratio

$(\mathrm{R} / \mathrm{C})=1$ usaha ternak sapi mencapai titik impas, yaitu tidak memperoleh keuntungan maupun menderita keuntungan (impas)

- $\quad$ Revenu costs ratio (R/C) $<1$ maka usaha ternak ternak sapi tidak layak diusahakan.

Untuk menguji perbedaan produktivitas ternak sapi IB dengan ternak sapi bukan IB, digunakan uji t-student tidak berpasangan.

Uji t-student tidak berpasangan ini berhubungan dengan varians dari dua populasi, maka perlu diketahui apakah dari dua populasi tersebut mempunyai varians sama atau berbeda.

\section{HASIL DAN PEMBAHASAN Keragaan Peternak}

Petani merupakan salah satu dari komponen pokok usahatani, disamping komponen lain yang berupa lahan, tanaman, ternak dan sarana produksi. Petani juga merupakan titik sentral dari seluruh aktivitas usahatani (Mosher 1978). Berkaitan dengan hal tersebut, unsur-unsur yang melekat pada individu petani sebagai pelaksana dan juga manajer usahatani akan menjadi faktor yang menentukan berhasil tidaknya usahatani yang dijalankan.

Berkaitan dengan pernyataan tersebut, Fadholi Hernanto (1979) menyatakan bahwa, paling tidak terdapat lima aspek yang mempengaruhi kemampuan petani dalam mengelola usahataninya yaitu: umur petani, pendidikan, kondisi ekonomi dan jumlah tanggungan keluarga, serta motivasi atau orientasi pengelolaan atas usahatani yang dijalankan. Kondisi kelima aspek petani dalam hal ini responden peternak sapi yang melaksanakan IB maupun tidak melakukan IB diuraikan secara singkat sebagai berikut.

\section{Umur Peternak}

Usahatani sekarang ini merupakan bidang usaha kurang diminati oleh generasi muda. Mereka lebih memilih mencari pekerjaan di sektor industri dan jasa atau perdagangan di perkotaan yang dapat memberikan harapan penghasilan lebih besar dengan beban risiko usaha yang relatif kecil. 


\section{AIMBAR AGRIBISNIS \\ ISSN 2460-4321}

Volume 1 - Nomor 3 - Juli 2016

Pada akhirnya kondisi seperti ini bertendensi mengarahkan usahatani hanya dikerjakan oleh orang-orang yang telah memiliki usia lanjut. Sementara umur petani yang sudah terlalu lanjut, selain kemampuan fisik yang menjadi pembatas, juga ada hambatan lain, berkaitan dengan motivasi untuk mencoba hal-hal baru sudah berkurang. Biro Pusat Statistik dalam survey kependudukan membedakan penduduk usia produktif dan penduduk tidak produktif. Penduduk usia produktif berkisar antara 15-64 tahun. Kurang dari atau sama dengan usia 14 tahun termasuk kategori anak-anak, sedangkan lebih dari 64 tahun termasuk kategori penduduk lanjut usia (lansia).

Berdasarkan data di lapangan peternak responden berusia antara 28-56 tahun. Berdasarkan ketegori yang telah dikemukakan, kelompok umur tersebut termasuk kategori usia produktif. Secara fisik mereka diharapkan mampu melakukan aktivitasnya tanpa kendala kemampuan fisik yang akan semakin menurun seiring dengan berlanjutnya usia.

Kelompok usia tersebut diharapkan masih dapat diharapkan memiliki semangat untuk melakukan introduksi iniviasi dalam upaya memperbaiki kinerja usaha ternaknya. Harapan ini penting karena inseminasi buatan yang menjadi topik kajian merupakan salah satu inivasi teknologi yang belum lama di terapkan di Kabupaten Tasikmalaya.Harapan tersebut cukup beralasan karena golongan umur peternak tersebut tidak terlalu jauh dari kisaran 25-40 tahun. Menurut Wiriaatmadja (1979), golongan umur 25-40 tahun merupakan golongan pengetrap dini, yaitu golongan yang mudah dibina sehingga dapat berperan dalam usaha penerapan teknologi. Selanjutnya menurut Wiriaatmadja, pada umur tersebut petani selalu termotivasi untuk mencoba halhal yang baru sehingga usaha peningkatan kemampuan teknis dapat dilakukan dengan baik secara mandiri.

\section{Pendidikan Peternak}

Berdasarkan hasil pengamatan peternak yang dijadikan responden pada umumnya hanya berpendidikan sekolah dasar (SD). Jumlah responden yang berpendidikan sekolah dasar mencapai komposisi diatas 49 persen, tamatan SLTP 30 persen.Sisanya dengan proporsi 21 adalah tamatan SLTA. Dalam kasus kajian ini secara kebetulan tidak ada peternak yang berpendidikan tamatan perguruan tinggi. Untuk lebih jelasnya proporsi jumlah peternak berdasarkan tingkat pendidikannya dapat dilihat dalam gambar berikut

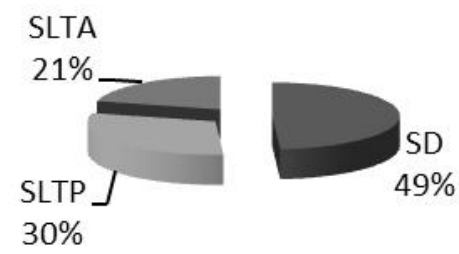

Gambar 2

Komposisi Jumlah Peternak Berdasarkan Tingkat Pendidikan

Berdasarkan gambaran tersebut di atas, tingkat pendidikan peternak pada umumnya rendah. Namun demikian tingkat pendidikan peternak yang rendah, terkompensasi dengan pengalaman usaha yang cukup lama. Diantara peternak responden ada yang sudah berpengalaman mencapai diatas sepuluh tahun menekuni usaha ternak sapi. Maka petani masih dapat diharapkan mengambil keputusankeputusan usaha yang tepat berdasarkan pada rasionalisasi pengalaman mereka.

\section{Kondisi Sosial Ekonomi Peternak}

Jumlah anggota keluarga ideal menurut konsep program Keluarga Berencana (KB) adalah empat orang, terdiri dari suami istri dan maksimal dua orang anak. Konsep keluarga demikian dikenal dengan Norma Keluarga Kecil

Bahagia dan Sejahtera (NKKBS).Berdasarkan hasil survey, pada umumnya jumlah anggota keluarga peternak lebih besar dari jumlah ideal NKKBS. Jumlah anggota keluarga peternak rata-rata terdiri dari empat orang, yaitu 3,6 orang dengan kisaran antara tiga sampai lima orang setiap keluarga peternak. Peternak yang terlalu banyak tanggungan keluarganya, berkecenderungan tidak memiliki kesempatan yang leluasa untuk investasi produktif pada usahaternaknya.Hal ini disebabkan kebutuhan primer mereka kadang-kadang melebihi 


\section{Kajian Aplikasi Teknologi Inseminasi Buatan Dalam Upaya Peningkatan Produktivitas Dan Pendapatan Usaha Ternak Sapi Potong \\ Di Kabupaten Tasikmalaya SUPRIANTO DAN DEDI DJULIANSAH}

penerimaan keluarga yang diperolehnya.Pada akhirnya, karena tidak ada investasi produktif, maka produktivitas usahatani rendah, dan penerimaan rendah. Begitu seterusnya kondisi petani membentuk siklus kemiskinan yang tidak berujung pangkal.

Berdasarkan hasil pengamatan dilapangan, keadaan ekonomi responden pada umumnya menunjukkan rata-rata kondisi ekonomi penduduk setempat.Petani sebagai ujung tombak pembangunan di sektor pertanian memiliki peran yang sangat strategis, seharusnya petani memiliki kesejajaran kondisi ekonomi dengan penduduk setempat pada umumnya, bahkan kalau memungkinkan kehidupan petani memiliki kesejahteraan ekonomi yang lebih baik dari keadaan ekonomi penduduk pada umumnya.

\section{Skala dan Orientasi Usaha Ternak}

Pada usahatani subsisten biasanya tidak terlalu ketat memperhitungkan nilai input dan output. Sedangkan pada usahatani komersial selain secara ketat memperhitungkan nilai input dan ouput, juga produk yang dihasilkan senantiasa berorientasi pasar. Orientasi pengelolaan ternak sapi sepunuhnya berorientasi komersial.

Skala usaha atau kepemilikan sapi potong di lokasi kajian adalah satu sampai 6 ekor per peternak.Kepemilikan yang relative ideal dibandingkan dengan kemampuan peternak yang menempatkan usaha ternak sapi sebagai usaha sampingan.

Rata-rata pengalaman peternak sudah diatas 5 tahun menekuni bidang usahanya, bahkan seperti telah disinggung sebelumnya, sudah ada peternak yang berpengalaman diatas 10 tahun. Namun demikian usaha ternak sapi bukan merupakan usaha pokok, mereka masih memiliki sumber pencaharian laian selain usaha ternak. Status pengelolaan ternnak sapi sebagai usaha pokok, akan mendorong peningkatan profesionalisme dan produktivitas dalam pengelolaan. Lain halnya dalam kedudukan sebagai usaha sampingan, cenderung kurang mendapat perhatian yang penuh.Pada akhirnya akan berimplikasi pada produktivitas dan rentabilitas usaha yang tidak maksimal.

\section{Produktivitas Usaha Ternak}

Salah satu dari dua tujuan penelitian ini adalah untuk mengetahui produktivitas usaha ternak sapi dengan perlakuan IB, dibandingkan dengan produktivitas usaha ternak sapi bukan IB. Dalam konsep proses produksi yang dikemukakan John P Doll dan Frank Orazem (1978), dikenal istilah produktivitas, begitu pula halnya yang dikemukakan Dabertin David. L (1986), keduanya memberikan pengertian yang sama, yaitu kemampuan satu satuan faktor produksi untuk menghasilkan sejumlah output. Secara matematis produktivitas dinyatakan dalam perbandingan jumlah output per satu satuan faktor produksi. Ouput suatu proses produksi kadang-kadang memerlukan lebih dari satu jenis faktor produksi, maka produktivitas satu proses produksi dapat dinnyatakan dalam berbagai macam, bentuk, tergantung banyaknya faktor produksi pembentuknya. Berdasarkan konsep produktivitas tersebut, maka produktivitas usaha ternak sapi dapat dinyatakan dalam bentuk jumlah anak per satu induk dalam kurun waktu terentu, atau bobot yang dicapai bakalan dalam periode waktu tertentu.

Konsep tersebut di atas mengarahkan cara pandang penatalaksanaan usaha ternak sapi kedalam dua tahapan, yang masing-masing berbeda cara pengukuran produktivitasnya. Produktivitas pada tahapan pertama adalah produktivitas pembiakan (reproduksi), yaitu produktivitas pemeliharaan induk dalam menghasilkan anak.Produktivitas usaha ternak sapi tahapan berikutnya adalah produktivitas usaha pembesaran anak atau dalam istilah yang biasa digunakan peternak disebut "bakalan".Usaha pembesaran dimaksudkan untuk menghasilkan sapi siap potong. Usaha ternak pembesaran adalah usaha memelihara sapi bakalan, dengan harapan akan mendapatkan hasil dari perkembangan bobot sapi yang semakin besar. Masing-masing tahapan usaha tersebut secara lebih rinci diuraikan sebagai berikut.

\section{Produktivitas Reproduksi}

Asumsi yang digunakan dalam penelitian perbandingan ini antara lain, jenis sapi induk yang diteliti adalah sapi lokal. Menurut Ismed 


\section{A MIMBAR A GRIBISNIS \\ ISSN 2460-432}

Volume 1 • Nomor 3 • Juli 2016

Pane (1986), yang termasuk dalam golongan sapi lokal adalah sapi sapi Bali, sapi Madura, sapi jawa dan sapi Sumatra. Berdasarkan penggolongan tersebut, sapi yang diamati yang ada pada peternak umumnya adalah jenis sapi Jawa, Asumsi berikutnya, keadaan awal induk sapi adalah mendekati kesetaraan, baik induk yang diberi perlakuan IB maupun tidak IB.
Segala sesuatu yang berkaitan dengan kondisi induk sapi tersebut, misal umur, bobot, dan lain sebagainya diasumsikan sama. Unsur pembedanya terletak pada aspek yang menjadi fokus penelitian ini, yaitu perlakuan IB dan tidak IB atau alamiah

Tabel 1

Tatalaksana Usaha Ternak Sapi IB Bukan IBPada Tahap Reproduksi

\begin{tabular}{|c|l|l|l|}
\hline No & \multicolumn{1}{|c|}{ Aspek Pengamatan } & \multicolumn{1}{c|}{ IB } & \multicolumn{1}{c|}{ Bukan IB } \\
\hline 1 & Induk & Jenis lokal & Jenis lokal \\
\hline 2 & Pakan & Hijauan, konsentrat & Hijuan, konsentrat \\
\hline 3 & Kandang & Lantai bambu/tembok & Lantai bambu/tembok \\
\hline 4 & Perkawinan & Artifisial & Alamiah \\
\hline 5 & Masa Kehamilan & \pm 9 bulan & \pm 9 bulan \\
\hline 6 & Tatalaksana Pemeliharaan & Standar & Standar \\
\hline 7 & Produktivitas anak/kelahiran & 1 ekor & 1 ekor \\
\hline
\end{tabular}

Penatalaksanaan induk baik dengan perlakuan IB maupun bukan IB, hampir tidak berbeda.Prasyarat kandang yang dianggap baik untuk sapi yang tidak di IB, juga merupakan prasyarat yang dianggap baik untuk sapi dengan perlakuan IB. Pakan yang diberikan untuk induk dengan perlakuan IB adalah pakan yang juga diberikan untuk sapi induk bukan IB.

Hal-hal yang dianggap baik untuk induk sapi yang di-IB adalah baik pula untuk sapi induk yang tidak di-IB. Perlakuan yang membedakan keduanya terletak pada proses perkawinan. Proses reproduksi bukan IB adalah proses reproduksi melalui perkawinan secara alamiah antara induk dengan jantan. Sedangkan proses reproduksi IB, adalah peristiwa induk sapi menerima sel jantan (spermatozoa) secara artifisial dengan bantuan peternak. Masa kehamilan hasil IB dengan kehamilan secara alamiah adalah sama, yaitu kurang lebih 9 bulan, sehingga sapi induk dari dua perlakuan tersebut pada bulan ke sepuluh secara teoritis melahirkan anak.

Jumlah anak sapi yang dihasilkan oleh induk IB, maupun bukan IB dalam satu masa reproduksi adalah sama, yaitu satu ekor. Menurut keterangan peternak, induk sapi beranak lebih dari satu ekor, merupakan kejadian langka, sehingga dalam analisis ini dianggap sebagai suatu pengecualian keistimewaan, yang jarang terjadi.Maka dari itu untuk keperluan kajian selanjutnya, diberlakukan pula asumsi hanya satu anak untuk satu induk.

Perlu menjadi catatan, walaupun jumlah anak untuk induk sapi IB maupun bukan IB adalah sama satu ekor, dalam satu kali masa reproduksi, namun keduanya melahirkan dengan bobot anak yang rata-rata berbeda. Bobot anak hasil IB menunjukkan rata-rata lebih besar daripada bobot anak bukan IB. Berdasarkan pengamatan di lapangan, bobot anak hasil IB berkisar $25-30 \mathrm{~kg}$, sedangkan bobot anak hasil kawin alamiah hanya mencapai $15-20 \mathrm{~kg}$.

Pada awal reproduksi, yaitu pada masa dimulainya perkawinan sampai melahirkan anak, sapi induk IB maupun bukan IB menunjukkan produktivitas yang sama, yaitu dapat menghasilkan satu anak dalam kurun waktu kurang lebih 10 bulan. Pada periode berikutnya, setelah masa sepuluh bulan, keadaan induk sapi yang diperlakukan IB dengan tidak IB mulai menunjukkan perbedaan.Perbedaan tersebut disebabkan oleh perkembangan anak sapi yang dilahirkan.Anak sapi hasil IB menunjukkan perkembangan yang lebih baik dibandingkan dengan perkembangan anak sapi bukan IB. Anak sapi menunjukkan perkembangan unggul yang mirip dengan keunggulan jenis sapi yang menjadi sumber semen. 


\section{Kajian Aplikasi Teknologi Inseminasi Buatan Dalam Upaya Peningkatan Produktivitas Dan Pendapatan Usaha Ternak Sapi Potong Di Kabupaten Tasikmalaya SUPRIANTO DAN DEDI DJULIANSAH}

Induk sapi lokal dengan perlakuan IB pada bulan yang ke 23 akan melahirkan anak yang kedua kalinya. Sedangkan induk sapi lokal yang dikawinkan secara almiah dengan pejantan lokal, baru melahirkan yang kedua kalinya pada bulan yang ke 29, sejak masa birahi periode yang pertama. Dengan kata lain introduksi IB, dapat mempercepat siklus reproduksi induk selama 6 bulan.

Percepatan siklus reproduksi induk, disebabkan oleh percepatan masa umur sapih.Anak sapi IB sudah disapih pada umur tiga bulan, sedangkan untuk anak sapi bukan IB, baru disapih induknya setelah berumur kurang lebih enam bulan.Salah satu karakter anak sapi IB, yang mendorong pertumbuhannya lebih cepat adalah menyusu lebih banyak dari anak sapi lokal. Maka dari itu, walaupun secara prinsipil, telah disinggung, perlakuan dalam penatalaksanaan induk yang di IB dan induk yang tidak di IB adalah sama, namun seyogyanya peternak memberikan tambahan pakan lebih banyak untuk sapi induk yang di IB. Tujuannya agar induk dapat memproduksi susu lebih banyak.

Selain siklus waktu yang lebih cepat, kelebihan lain yang didapat dari perlakuan IB diantaranya, anak atau "bakalan" yang dihasilkan memiliki kualitas yang relatif lebih unggul dari bakalan yang dihasilkan dengan kawin secara alamiah. Salah satu keunggulan dari bakalan hasil IB adalah, pertumbuhan yang relatif lebih cepat. Bakalan hasil IB memiliki karakteristik keunggulan hampir sama dengan jenis sapi yang dijadikan sumber semen. Apabila sumber semen berasal dari jenis Brahman, maka bakalan yang dihasilkan mendekati karakteristik Brahman, begitu pula halnya apabila semen berasal dari jenis sapi yang lain. Berdasarkan hasil pengamatan di lapangan, jenis sapi yang disukai peternak sebagai sumber semen adalah jenis peranakan sapi Onggole, Simantal, Brahman, dan Limousin.

Tabel 2

Masa Perkembangan Reproduksi Induk Sapi IB dan Bukan IB

\begin{tabular}{|c|l|l|}
\hline \multirow{2}{*}{$\begin{array}{c}\text { Bulan } \\
\text { Ke }\end{array}$} & \multicolumn{2}{|c|}{ PERKEMBANGAN REPRODUKSI INDUK LOKAL } \\
\cline { 2 - 3 } & \multicolumn{1}{|c|}{ IB } & \multicolumn{1}{c|}{ BUKAN IB } \\
\hline 1 & Proses Kawin Buatan & Proses Kawin Alamiah \\
\hline 2 & Masa Kehamilan & Masa Kehamilan \\
\hline 3 & Masa Kehamilan & Masa Kehamilan \\
\hline dst & Masa Kehamilan & Melahirkan /menyusui \\
\hline 9 & Melahirkan /menyusui & Masa menyusui \\
\hline 10 & Masa menyusui & Masa menyusui \\
\hline 11 & Masa menyusui & Masa menyusui \\
\hline 12 & Anak disapih & Masa menyusui \\
\hline 13 & Masa pemulihan & Anak disapih \\
\hline 14 & Masa Birahi Berikutnya & Masa pemulihan \\
\hline 15 & Masa Kehamilan berikutnya & Masa Birahi Berikutnya \\
\hline 16 & Masa Kehamilan berikutnya & Masa Kehamilan berikutnya \\
\hline 17 & Masa Kehamilan berikutnya & Masa Kehamilan berikutnya \\
\hline dst & Masa Kehamilan berikutnya & Masa kehamilan berikutnya \\
\hline 23 & Melahirkan yg kedua kali & Masa kehamilan berikutnya \\
\hline 24 & Masa Menyusui & \\
\hline
\end{tabular}

Berdasarkan uraian di atas dapat disimpulkan bahwa produktivitas induk sapi yang di IB dan induk sapi dengan perkawinan alamiah adalah sama. Perbedaannya terletak pada interval kelahiran yang lebih singkat dan kualitas anak hasil IB yang lebih baik.Induk sapi yang di IB 5-6 bulan lebih cepat untuk sampai pada masa melahirkan berikutnya.

\section{Produktivitas Pembesaran}

Fokus kajian produktivitas usaha pembesaran ternak sapi, terletak pada pertumbuhan bobot anak sapi dalam satu 


\section{A MIMBARIS \\ ISSN 2460-4321 \\ Volume 1 • Nomor 3 • Juli 2016}

satuan waktu tertentu, dengan pemberian jenis dan jumlah pakan tertentu. Untuk mempermudah pemahaman uraian selanjutnya, dibawah ini disajikan Tabel 5.3 hasil pengamatan terhadap usaha ternak sapi yang membesarkan anak sapi hasil IB dan peternak yang membesarkan anak sapi bukan hasil IB.

Tabel 3.

Karakteristiik Usaha Ternak Pembesaran Sapi Bakalan Hasil IB dan Bukan IB

\begin{tabular}{|c|c|c|}
\hline Karakteristik & Bakalan IB & Bakalan Bukan IB \\
\hline Induk & lokal & Lokal \\
\hline Bobot lahir & $(25-30) \mathrm{kg}$ & $(15-20) \mathrm{kg}$ \\
\hline Umur sapih & $(3-4) \mathrm{bulan}$ & $(6-8) \mathrm{bulan}$ \\
\hline Bobot sapih & $(105-110) \mathrm{kg}$ & $(65-75) \mathrm{kg}$ \\
\hline Harga Jual Sapih & $\mathrm{Rp}(2.500 .000-2.750 .000)$ & $\mathrm{Rp}(1000.000-1.500 .000)$ \\
\hline Umur Bakalan & 12 bulan & 18 bulan \\
\hline Bobot Bakalan & $(250-300) \mathrm{kg}$ & $(175-200) \mathrm{kg}$ \\
\hline Harga Bakalan & $\mathrm{Rp}(4.000 .000-4.500 .000)$ & $\mathrm{Rp}(2.000 .000-2.500 .000)$ \\
\hline
\end{tabular}

Bobot lahir anak sapi IB dari induk lokal mencapai $(25-30) \mathrm{kg}$, jauh lebih besar dari bobot anak sapi bukan IB dari iduk lokal yang hanya mencapai (5-20) kg.Anak sapi hasil IB pada umur (3-4) bulan sudah disapih induknya, sementara anak sapi lokal, baru disapih setelah berumur (6-8) bulan. Anak sapi yang biasa diperjual belikan, disebut "bakalan" biasanya telah berumur 12 bulan untuk anak sapi IB dan harus menunggu sampai berumur (8-24) bulan untuk anak sapi lokal.

Perkembangan berikutnya, bakalan hasil IB menunjukkan pertumbuhan bobot yang relatif lebih cepat, dibandingkan dengan pertumbuhan bakalan yang bukan hasil IB. Hal ini diduga berkaitan dengan keragaan fisik bakalan hasil hasil IB, lebih baik daripada keragaan fisik bakalan lokal. Hal ini dicirikan dari rangka anak sapi IB, lebih besar dari rangka anak sapi lokal. Hal ini berimplikasi pada konsumsi pakan yang relatif lebih besar per satuan waktu untuk bakalan hasil IB. Secara teoritis mudah dipahami, perkembangan bakalan hasil IB, mirip dengan pejantan sumber semennya, sehingga memerlukan pengisian daging yang lebih besar pula. Bakalan hasil IB memerlukan waktu yang lebih pendek untuk mencapai bobot yang sama dengan bakalan bukan hasil IB. Dengan kata lain, pada masa pertumbuhan yang sama, bobot yang dicapai bakalan hasil IB relatif lebih besar dari bobot bakalan lokal. Berdasarkan hasil pengamatan peternak, perkembangan bobot anak sapi IB dan bukan IB dapat dilihat dalam Gambar 3

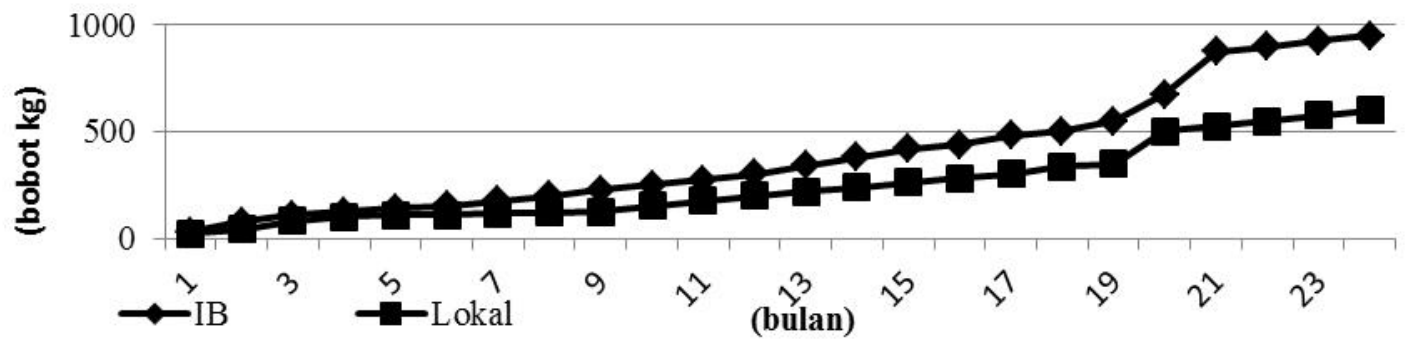

Gambar 3

Perkembangan Bobot Sapi Hasil IB dan Bukan IB

Halaman | 220 


\section{Kajian Aplikasi Teknologi Inseminasi Buatan Dalam Upaya Peningkatan Produktivitas Dan \\ Pendapatan Usaha Ternak Sapi Potong \\ Di Kabupaten Tasikmalaya \\ SUPRIANTO DAN DEDI DJULIANSAH}

Uraian tersebut diatas, diperkuat denganhasil pengujian statistik t-student pada selang kepercayaan 95 persen, thitung $=3,730$ lebih besar dari t-tabel $=1,70$ Keputusan statistiknya, Ho ditolak, signifikan. Hal ini berarti hasil pengamatan menunjukkan produktivitas pembesaran anak sapi IB lebih besar daripada produktivitas anak sapi bukan hasil IB. Untuk lebih jelasnya pembaca dapat melihat hasil pengujian selengkapnya dalam lampiran.

\section{Pendapatan Usaha Ternak}

Pendapatan dalam uraian terdahulu didefinisikan sebagai selisih antara besarnya penerimaan usahatani dengan biaya-biaya yang telah dikeluarkan dalam proses usahatani tersebut. Penerimaan adalah volume produksi dikalihkan dengan harga per satuan produk, sementara biaya usahatani terdiri dari baya tetap dan biaya variabel.Dalam penelitian ini penerimaan adalah hasil penjualan anak sapi, sedangkan biaya usahatani adalah biaya-biaya yang dikeluarkan untuk pemeliharaan anak sapi tersebut sampai siap jual.

Berdasarkan hasil analisis statistik tstudent, pada selang kepercayaan 95 persen, $\mathrm{df}=30$, diperoleh nilai thitung $=3,730$ yang lebih besar dari t tabel pada df yang sama yaitu 1,70 Keputusan statistiknya Ho ditolak, signifikan. Sesuai dengan format analisis yang telah dirumuskan sebelumnya, hal ini berarti pendapatan usaha ternak dengan IB lebih besar dari pendapatan usaha ternak tidak IB.
Penjelasan lebih rinci perbedaan pendapatan tersebut diuraikan sebagai berikut.Usaha ternak sapi IB, pada tahapan reproduksi maupun tahapan pembesaran menunjukkan produktivitas yang lebih tinggi dibandingkan dengan produktivitas sapi tidak di IB.Umur sapih anak sapi IB, hanya 3 bulan jauh lebih singkat daripada umur sapih sapih anak bukan IB yang mencapai 6 bulan. Begitu pula halnya pada tahapan pembesaran, untuk mencapai volume produksi siap potong, ternak bakalan IB memerlukan waktu yang lebih singkat, yaitu kurang lebih 12 bulan, sementara sapi bukan IB baru mencapai siap potong setelah berumur 1,5 - 2 tahun.

Konsekuensi logis dari fenomena tersebut, bakalan IB dapat memotong biaya pemeliharaan selama 6 bulan, namun demikian, karena konsumsi pakan bakalan IB lebih besar, pemotongan waktu tersebut seolah-olah terkompensasi dengan volume pakan yang besar. Perimbangan besarnya penerimaan dan biaya produksi dapat dilihat dalam Tabel 5.4.

Penerimaan rata-rata peternak sapi potong yang melakukan aplikasi IB relatif lebih besar dari penerimaan rata-rata peternak sapi potong bukan IB. Begitu pula komponen biaya yang dikeluarkan peternak sapi potong IB lebih besar dari biaya peternak sapi potong bukan IB. Pada akhirnya rata-rata pendapatan yang diterima usaha ternak IB mencapai $\mathrm{Rp}$ 12.972.667, sedangkan pendapatan rata-rata peternak sapi potong bukan IB $\mathrm{Rp} 4.955 .756$

Tabel 4 Rata-rata Penerimaan, Biaya dan Pendapatan UsahaTernak Sapi IB dan Bukan IB

\begin{tabular}{|c|c|c|}
\hline Komponen & Bakalan IB & Bakalan Alamiah \\
\hline I. Penerimaan Hasil Penjualan & 19.130 .667 & 7.996 .786 \\
\hline II. Jumlah Biaya & 6.158 .000 & 3.041 .029 \\
\hline III. Pendapatan Usaha Ternak & 12.972 .667 & 4.955 .756 \\
\hline V. Rasio Penerimaan - Biaya (R/C) & 3,17 & 2,96 \\
\hline
\end{tabular}

Beberapa komponen biaya usaha ternak sapi potong ini nilainya terlalu kecil dibandingkan dengan komponen biaya lain, sehingga dalam perhitungan diabaikan, tidak dimasukkan dalam perhitungan ini.
Komponen biaya usaha ternak dimaksud adalah: Sewa lahan, bunga biaya variabel, dan penyusutan alat. Lebih lengkapnya komponen biaya per peternak dapat dilihat dalam lampiran. 


\section{A MIMBBAR}

ISSN 2460-4321

Volume 1 • Nomor 3 • Juli 2016

Angka-angka tersebut diatas sudah dapat mengindikasikan bahwa usaha ternak sapi potong IB, memerlukan investasi produktif yang lebih besar dibandingkan dengan investasi produktif pada usaha ternak sapi potong bukan IB. Paling tidak, usaha ternak sapi potong dengan IB memerlukan biaya tambahan untuk perlakuan IB itu sendiri. Disamping itu, peternak sapi potong IB memerlukan biaya yang relatif besar karena pakan sapi IB selain proporsinya yang lrelatif lebih besar, juga harus dibarengi dengan kualitas pakan yang relatif lebih baik dari kualitas pakan pada umumnya.

Ternak sapi potong lokal, kalaupun jumlah dan kualitas pakan ditingkatkan, tidak akan mendapatkan hasil seperti yang dicapai sapi potong dengan perlakuan IB. Hal ini terkait dengan faktor genetik yang menjadi pembatas. Sebaliknya, sapi potong hasil inseminasi buatan yang diberi pakan dengan standar pakan sapi potong lokal juga tidak akan mencapai hasil yang optimal. Sapi potong unggul memerlukan paket perlakuan dan teknologi serta kualitas pekan tertentu, sehingga apabila tidak terpenuhi paket tersebut pertumbuhan sapi potong tidak akan maksimal sesuai dengan potensi genetiknya.

Perimbangan penerimaan dengan biaya (R/C Rasio) pada usaha ternak sapi potong IB adalah 3,17 , artinya setiap rupiah biaya yang diinvestasikan pada usaha ternak sapi potongdengan aplikasi teknologi IB mendapatkan kompensasi penerimaan sebesar 3,17 rupiah. R/C rasio yang dicapai usaha ternak sapi potong bukan IB adalah 2,96, artinya untuk setiap rupiah biaya yang diinvestasikan pada usaha ternak sapi potong bukan IB mendapatkan kompensasi penerimaan sebesar 2,96 rupiah. Apabila perhitungan tersebut dinyatakan dalam konsep pendapatan, maka setiap rupiah biaya yang dikeluarkan memperoleh pendapatan 2,17rupiah untuk usaha ternak sapi potong IB dan pendapatan sebesar Rp 1,96 untuk usaha ternak sapi potong bukan IB. Apabila dinyatakan dalam persentase, pendapatan usaha ternak sapi potong IB mencapai 67,81 persen, sementara usaha ternak sapi potong bukan IB mencapai 61,97 persen dalam satu siklus produksi.

Durasi investasi satu siklus produksi pada usaha ternak sapi potong IB (12 bulan), lebih lama dibandingkan dengan durasi investasi pada usaha ternak sapi potong bukan IB yang mencapai 18 bulan. Maka pendapatan rata-rata usaha ternak sapi potong IB setara dengan 5,65 persen dari total investasi per bulan, sedangkan pendapatan yang diperoleh dari usaha ternak sapi potong bukan IB hanya 3,44 persen per bulan.

Kedua jenis usaha tersebut layak dilakukan, namun paling layak diantara keduanya, adalah usaha terank sapi potong dengan perlakuan IB. Usaha ternak sapi potong dengan perlakuan IB memerlukan biaya yang lebih besar, namun penerimaan yang diharapkanpun lebih besar lagi.Marginal cost relatif lebih kecil dibandingkan dengan marginal revenue.

\section{Manfaat dan Risiko Aplikasi IB}

Bobot sapi potong IB sejak lahir sampai masa perkembangan hingga siap potong selalu lebih tinggi dari sapi potong bukan IB. Lebih penting lagi, perlakuan IB dalam jangka panjang akan menghasilkan kualitas sapi yang semakin baik. Apabila sapi potong lokal di IB akan menghasilkan anak sapi potong yang mewarisi kurang lebih 25 persen karakteristik jantan yang dijadikan sumber semen. Selanjutnya, apabila anak sapi potong hasil IB tersebut di IB lagi pada masa kehamilannya, akan menghasilkan anak sapi sapi potong yang mewarisi 50 persen karakteristik sapi jantan. Perlakuan yang sama terhadap anak-anak sapi berikutnya, maka apabila sudah sampai pada anak sapi generasi yang ke empat, akan menghasilkan jenis sapi potong yang hampir 100 persen mendekati karakteristik keunggulan sapi jantannya. Tentu saja uraian tersebut dengan asumsi bahwa sapi yang dilahirkan berkelamin betina, sehingga anak yang dilahirkan akan dapat di IB kembali untuk menghasilkan generasi berikutnya.

Perbaikan mutu sapi berdasarkan pendekatan IB dapat ditempuh setelah melalui 


\section{Kajian Aplikasi Teknologi Inseminasi Buatan Dalam Upaya Peningkatan Produktivitas Dan Pendapatan Usaha Ternak Sapi Potong \\ Di Kabupaten Tasikmalaya \\ SUPRIANTO DAN DEDI DJULIANSAH}

tiga generasi, karena baru pada generasi yang ke empat, anak sapi yang dilahirkan mendekati karakteristik penuh jenis sapi jantannya. Apabila diasumsikan anak sapi mencapai masa reproduksi pada umur 2 tahun, Maka diperkirakan dalam kurun waktu $8-10$

\section{Gambar 4}

\section{Proses Peningkatan Kualitas Sapi Melalui IB}

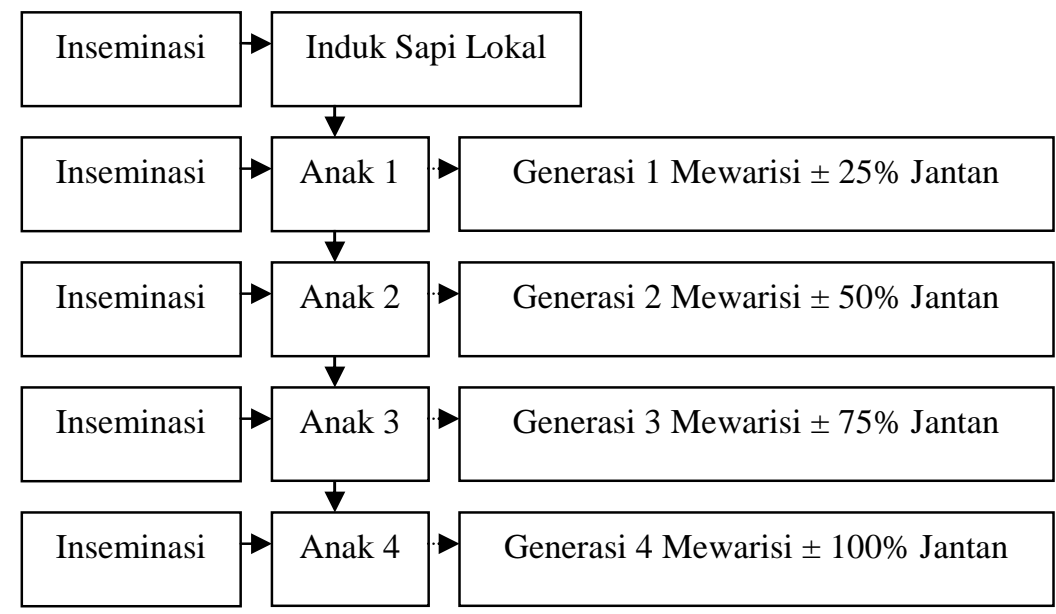

Dalam kenyataannya, para peternak tidak melakukan program IB secara sistematis, dalam perencanaan yang matang. Perlakuan IB hanya dilakukan spontanitas, tidak dibarengi dengan program yang jelas. Misal, hasil IB sekalipun betina, jarang yang dijadikan induk untuk generasi berikutnya.Petani lebih suka memelihara induk yang dimiliki pertama kali, daripada memelihara anak.Maka kejadiannya, program inseminasi buatan dalam skala makro menjadi terputus, karena generasi sapi hasil IB selalu berakhir di rumah potong sebelum berkembang pada generasi berikutnya.

Perilaku petani seperti ini di sisi lain ada juga sisi positifnya. Program Inseminasi Buatan dalam jangka panjang akan mencemari atau mungkin saja akan menghilangkan spesies lokal murni. Sementara keberadaan spesies lokal murni masih harus dipertahankan keberadaannya sebagai sumber plasma.Maka dari itu program IB idealnya harus dibarengi dengan upaya konservasi pemurnian jenis-jenis sapi lokal.Ketergantungan pada salah satu jenis spicies ternak tertentu sangat berisiko fatal dan masal terhadap serangan tahun sudah diperoleh generasi sapi yang bermutu hampir sama dengan jenis jantan yang digunakan sebagai sumber semen. Proses perbaikan mutu sapi lokal dengan IB dapat dilihat Gambar 5.3 berikut.
penyakit.Sebaliknya, keragaman jenis merupakan upaya tidak langsung membagi risiko.

\section{KESIMPULAN DAN SARAN \\ Kesimpulan}

Berdasarkan hasil pengamatan dan pembahasan yang telah diuraikan, hasil penelitian ini dapat disumpulkan sebagai berikut.

\section{Produktivitas Usaha}

Berdasarkan hasil analisis jumlah anak per satu induk, produktivitas induk sapi potong yang di IB dan sapi potong bukan IB adalah sama, yakni hanya menghasilkan satu ekor anak dalam satu masa reproduksi. Sementara berdasarkan perhitungan jumlah anak per satuan waktu, sapi lokal induk yang di IB menunjukkan produktivitas yang lebih tinggi, karena memiliki interval waktu yang lebih singkat untuk sampai pada masa reproduksi berikutnya, pada bulan ke 23 induk sapi yang di IB sudah dapat melehirkan anak yang kedua kali. Padahal untuk sapi potong yang tidak di IB, paling cepat baru akan melahirkan anak pada bulan yang ke 25 . 


\section{A MIMBBAR \\ ISSN 2460-4321 \\ Volume 1 • Nomor 3 • Juli 2016}

Berdasarkan analisis perkembangan bobot tubuh persatuan waktu, Usaha pembesaran anak hasil IB menunjukkan produktivitas yang lebih tinggi dibandingkan dengan produktivitas pembesaran anak sapi lokal. Anak sapi hasil IB sudah mencapai 105$110 \mathrm{~kg}$ pada umur sapih 4 bulan, sedangkan sapi bukan IB baru mencapai bobot $65-75 \mathrm{~kg}$ pada umur sapih yang lebih lama, yaitu 6-8 bulan.

\section{Pendapatan Usaha Ternak.}

Implikasi dari produktivitas yang lebih tinggi, pendapatan usaha ternak IB mencapai 5,65 persen dari total investasi per bulan, lebih besar dibandingkan dengan pendapatan usaha ternak bukan IB yang hanya mencapai 3,44 persen per bulan.

\section{Saran}

$\begin{array}{lll} & \text { Berdasarkan kesimpulan tersebut } \\ \text { maka dapat disarankan hal-hal sebagai }\end{array}$ berikut:

Peternak sapi potong disarankan mengikuti program Inseminasi Buatan karena telah teruji dapat memberikan pendapatan usaha yang lebih besar dibandingkan dengan usaha ternak yang tidak mengikuti program IB.

Aplikasi teknologi inseminasi buatan sapi potong untuk memerlukan biaya tambahan yang menurut kondisi ekonomi petani pada umumnya, kurang mampu menyediakan biaya tersebut. Dalam kondisi seperti ini hendaknya dibentuk suatu kelembagaan yang dapat menjembatani kekurangan petani dengankebutuhannya.

Aplikasi tekonlogi inseminasi buatan hendaknya tidak dilakukan secara spontan dan sporadis, namun harus direncanakan secara sistematis berkelanjutan, dengan tujuan untuk memperbaiki sifat-sifat genetik sapi lokal dalam jangka panjang.

Kemurnian genetik sapi potong lokal harus tetap dipertahankan, dilestarikan, karena bagaimanapun jenis sapi lokal memeiliki keunggulan. Misal, sapi potong lokal dapat tercukupi dengan pakan yang hanya berbasis sumberdaya lokal.

\section{DAFTAR PUSTAKA}

Abas Tjakrawiralaksana,1983. Ilmu Usaha Tani. Departemen Ilmu-ilmu Sosial Ekonomi Pertanian. Fakultas Pertanian Institut Pertanian Bogor. Bogor.

Atmadilaga,D.1977, Masalah dan Masa Depan Industri Perunggasan diIndonesia, Makalah Seminar, pada Tanggal 30-31 Mei 1977 Tentang Ilmu dan Industri Perunggasan, Cisarua

Atmadilaga,D.1991. Modernisasi Peternakan Ditinjau dari Segi Potensi dan Masalah Gizi, Bahan Diskusi Panel "Sumbangan Pendidikan Tinggi Peternakan Kepada Pembangunan Peternakan"

Badan Pusat Statistik, Kabupaten Tasikmalaya Dalam Angka 2014. Bapeda Kabupaten Tasikmalaya dan Kantor statistik Kabupaten Tasikmalaya.

Christiansen, SB dan Sandoe.P. 2000.Bioetich:Limit to The Interference With life. Anim. Reprod sci.

Dabertin. David L. 1986. Agricultural Production economics. Macmilan Publishing Company. New York.

Dinas Peternakan Perikanan dan Kelautan Kabupaten Tasikmalaya. 2014. Laporan Tahunan. Tasikmalaya.

Direktorat Jendral Peternakan Sub Bina Penyuluhan, 1990, Pedoman Faktor Penentu Teknis Peternakan. Jakarta.

Doll John P and Frank Orazem, 1978. Production Economics Theory With Application. Grid Inc.Columbus, Ohio.

Fadholi Hernanto, 1979. Ilmu Usaha Tani. Departemen Sosek Fakultas Pertanian IPB. Bogor

Hafez E.S.E. 2003. Reproduction In Farm Animal 6 th Edition. Lea and Fabiger. Filadelphia.

Ismed Pane. 1986. Pemuliaan Ternak Sapi. Penerbit Gramedia. Jakarta.

Rasyaf. M. 2006. Memasarkan Hasil Petrernakan. Penebar Swadaya. Jakarta. 
Kajian Aplikasi Teknologi Inseminasi Buatan Dalam Upaya Peningkatan Produktivitas Dan Pendapatan Usaha Ternak Sapi Potong

Di Kabupaten Tasikmalaya

SUPRIANTO DAN DEDI DJULIANSAH

Rusastra, E.M. Yusmuchad Yisdja, Sumaryanto, Delima, H. Darmawan, A.Djatiharti., 1988, Penelitian Analisis Finansial dan Ekonomi Kelembagaan Perusahaan Inti Rakyat Perunggasan, Pusat Penelitian Agro Ekonomi, Badan Litbang Pertanian, Departemen Pertanian Bogor.

Soebandi Partodihardjo. 1982. Ilmu Reproduksi Hewan. Mutiara Sumber Widya. Jakarta.

Soedarsono Hadisaputro 1977. Biaya dan Pendapatan di Dalam Usahatani. Departemen Ekonomi Pertanian Fakultas Pertanian. UGM. Yogyakarta.

Sudjana, 1996. Metode Statistik. Penerbit Tarsito. Bandung.

Tambing SN, Toelihere, MR dan Yusuf TL. 2000. Optimasi Program Inseminasi Buatan Pada Kerbau. Wartazoa.

Tambing SN. 2001. Peranan Bioteknologi. Inseminasi Buatan. Dalam Pembinaan Produksi Peternakan: Suatu Tinjauan Filsafat Sains. Institut Pertanian Bogor.

Toelihere, MR. 1985. Inseminasi Buatan Pada Ternak. Edisi ke 2. Angkasa. Bandung.

Umar, Husein, 2000. Metode Penelitian Untuk Skripsi dan Tesis Bisnis.PT Raja Grafindo Persada. Jakarta.

Wiyandi, $\quad$ S., $\quad 1988, \quad$ Pengantar Kewiraswastaan, Penerbit Sinar Baru, Bandung. 


\section{AIMBAR AgRIBISNIS \\ ISSN 2460-4321 \\ Volume 1 • Nomor $3 \bullet$ Juli 2016}

